\title{
Potassium-Coupled Chloride Cotransport Controls Intracellular Chloride in Rat Neocortical Pyramidal Neurons
}

\author{
R. Anthony DeFazio, Sotirios Keros, Michael W. Quick, and John J. Hablitz \\ Department of Neurobiology, University of Alabama at Birmingham, Birmingham, Alabama 35294
}

\begin{abstract}
Chloride $\left(\mathrm{Cl}^{-}\right)$homeostasis is critical for many cell functions including cell signaling and volume regulation. The action of $\mathrm{GABA}$ at $\mathrm{GABA}_{\mathrm{A}}$ receptors is primarily determined by the concentration of intracellular $\mathrm{Cl}^{-}$. Developmental regulation of intracellular $\mathrm{Cl}^{-}$results in a depolarizing response to GABA in immature neocortical neurons and a hyperpolarizing or shunting response in mature neocortical neurons. One protein that participates in $\mathrm{Cl}^{-}$homeostasis is the neuron-specific $\mathrm{K}^{+}-\mathrm{Cl}^{-}$cotransporter (KCC2). Thermodynamic considerations predict that in the physiological ranges of intracellular $\mathrm{Cl}^{-}$and extracellular $\mathrm{K}^{+}$concentrations, KCC2 can act to either extrude or accumulate $\mathrm{Cl}^{-}$. To test this hypothesis, we examined KCC2 function in pyramidal cells from rat neocortical slices in mature (18-28 d postnatal) and immature (3-6 d postnatal) rats. Intracellular $\mathrm{Cl}^{-}$ concentration was estimated from the reversal potential of whole-cell currents evoked by local application of exogenous
\end{abstract}

GABA. Both increasing and decreasing the extracellular $\mathrm{K}^{+}$concentration resulted in a concomitant change in intracellular $\mathrm{Cl}^{-}$ concentration in neurons from mature rats. KCC2 inhibition by furosemide caused a change in the intracellular $\mathrm{Cl}^{-}$concentration that depended on the concentration of pipette $\mathrm{Cl}^{-}$; in recordings with low pipette $\mathrm{Cl}^{-}$, furosemide lowered intracellular $\mathrm{Cl}^{-}$, whereas in recordings with elevated pipette $\mathrm{Cl}^{-}$, furosemide raised intracellular $\mathrm{Cl}^{-}$. In neurons from neonatal rats, manipulation of extracellular $\mathrm{K}^{+}$had no effect on intracellular $\mathrm{Cl}^{-}$ concentration, consistent with the minimal KCC2 mRNA levels observed in neocortical neurons from immature animals. These data demonstrate a physiologically relevant and developmentally regulated role for $\mathrm{KCC}$ in $\mathrm{Cl}^{-}$homeostasis via both $\mathrm{Cl}^{-}$extrusion and accumulation.

Key words: potassium chloride cotransporter; GABA receptors; KCC2; development; chloride homeostasis; rt-PCR
The principal inhibitory neurotransmitter in the neocortex is GABA. Early studies in vivo demonstrated that fast IPSPs and responses to iontophoretically applied GABA have similar reversal potentials and ionic sensitivities (Krnjevic and Schwartz, 1967; Dreifuss et al., 1969). Subsequent studies in vitro showed that both GABA responses and IPSPs reverse near the expected chloride $\left(\mathrm{Cl}^{-}\right)$equilibrium potential and are blocked by bicuculline, suggesting mediation by $\mathrm{GABA}_{\mathrm{A}}$ receptors $\left(\mathrm{GABA}_{\mathrm{A}} \mathrm{Rs}\right)$ (Weiss and Hablitz, 1984; Howe et al., 1987). The main permeant ion of $\mathrm{GABA}_{\mathrm{A}}$ receptor channel complexes is $\mathrm{Cl}^{-}$, although permeability to bicarbonate ions has been demonstrated (Bormann et al., 1987; Kaila et al., 1993). The membrane potential and the transmembrane gradients of permeant ions determine ionic flux through the $\mathrm{GABA}_{\mathrm{A}}$ receptor. In most mature neurons, the resting potential is close to the $\mathrm{Cl}^{-}$equilibrium potential, and activation of $\mathrm{GABA}_{\mathrm{A}}$ Rs results in shunting inhibition (Andersen et al., 1980); i.e., activation of $\mathrm{GABA}_{\mathrm{A}}$ receptors with minimal net ionic flux results in decreased excitability. If the neuron is depolarized relative to the $\mathrm{Cl}^{-}$equilibrium potential, $\mathrm{GABA}_{\mathrm{A}}$ receptor activation results in an inward flux of $\mathrm{Cl}^{-}$that hyperpolarizes the neuron. Immature neocortical neurons have an elevated $\left[\mathrm{Cl}^{-}\right]_{\mathrm{i}}$, and $\mathrm{GABA}_{\mathrm{A}} \mathrm{R}$ activation results in a depolarizing response to GABA (Owens et al., 1996).

Electroneutral cotransport of $\mathrm{Cl}^{-}$ions plays a critical role in $\left[\mathrm{Cl}^{-}\right]_{\text {i }}$ homeostasis (see Alvarez-Leefmans, 1990; Kaila et al., 1993). One mechanism for accumulating $\mathrm{Cl}^{-}$is the $\mathrm{Na}^{+}-\mathrm{K}^{+}-2$ $\mathrm{Cl}^{-}$cotransporter (NKCC) (Kakazu et al., 1999). The primary $\mathrm{Cl}^{-}$extrusion mechanism is $\mathrm{K}^{+}-\mathrm{Cl}^{-}$cotransport (AlvarezLeefmans, 1990). A neuron-specific form of the ubiquitous $\mathrm{K}^{+}$coupled $\mathrm{Cl}^{-}$cotransporter (KCC2) has been characterized re-

Received May 5, 2000; revised Aug. 7, 2000; accepted Aug. 10, 2000.

This work was funded by the American Epilepsy Society with support from the Milken Family Foundation (R.A.D.) and National Institute of Neurological Disorders and Stroke Grant NS-22373 (J.J.H.). We wish to thank Alison Margolies for excellent technical assistance.

Correspondence should be addressed to Dr. John J. Hablitz at the above address. E-mail: hablitz@nrc.uab.edu.

Copyright (C) 2000 Society for Neuroscience $0270-6474 / 00 / 208069-08 \$ 15.00 / 0$ cently (Payne, 1997; Rivera et al., 1999; Williams et al., 1999). The expression of this transporter increases with development and is believed to support the developmental changes in $\mathrm{GABA}_{\mathrm{A}} \mathrm{R}$ mediated signaling (Lu et al., 1999; Rivera et al., 1999).

The direction of $\mathrm{K}^{+}-\mathrm{Cl}^{-}$cotransport is determined by the transmembrane $\mathrm{K}^{+}$and $\mathrm{Cl}^{-}$gradients. Under conditions of low $\left[\mathrm{Cl}^{-}\right]_{\mathrm{i}}$ and elevated $\left[\mathrm{K}^{+}\right]_{\mathrm{o}}$, thermodynamic considerations suggest that $\mathrm{KCC} 2$ could operate in reverse to accumulate $\mathrm{Cl}^{-}$(Payne, 1997; Jarolimek et al., 1999; see also Kakazu et al., 2000). A role for $\mathrm{KCC} 2$ in maintaining $\left[\mathrm{K}^{+}\right]_{\mathrm{o}}$, i.e., that $\mathrm{KCC} 2$ could lower $\left[\mathrm{K}^{+}\right]_{\mathrm{o}}$ by cotransport of $\mathrm{K}^{+}$and $\mathrm{Cl}^{-}$ions into neurons, has also been proposed (Payne, 1997). A consequence of such a mechanism would be the accumulation of $\left[\mathrm{Cl}^{-}\right]_{\mathrm{i}}$, a phenomenon consistent with activity-dependent decreases in GABAergic inhibition (Thompson and Gähwiler, 1989a; Ling and Benardo, 1995).

In the present study, we tested the hypothesis that developmental changes in the expression of $\mathrm{KCC} 2$ result in the coupling of $\left[\mathrm{Cl}^{-}\right]_{\mathrm{i}}$ and $\left[\mathrm{K}^{+}\right]_{\mathrm{o}}$ via the activity of the furosemide-sensitive $\mathrm{K}^{+}$-coupled $\mathrm{Cl}^{-}$cotransporter. Our results demonstrate that manipulations of $\left[\mathrm{K}^{+}\right]_{\mathrm{o}}$ and furosemide altered $\left[\mathrm{Cl}^{-}\right]_{\mathrm{i}}$ in a manner consistent with either accumulation or extrusion of $\mathrm{Cl}^{-}$via a $\mathrm{K}^{+}$-coupled $\mathrm{Cl}^{-}$ cotransport mechanism. $\left[\mathrm{K}^{+}\right]_{\mathrm{o}}$ manipulations in immature neurons had no effect on $\left[\mathrm{Cl}^{-}\right]_{\mathrm{i}}$, consistent with the low expression of $\mathrm{KCC} 2$ mRNA detected in cytoplasm harvested from these cells. Expression of $\mathrm{KCC} 2$ results in lowered $\left[\mathrm{Cl}^{-}\right]_{\mathrm{i}}$ and translates physiological changes in $\left[\mathrm{K}^{+}\right]_{\mathrm{o}}$ to marked changes in $\left[\mathrm{Cl}^{-}\right]_{\mathrm{i}}$.

\section{MATERIALS AND METHODS}

Brain slice preparation, maintenance, and electrophysiological recording. Animals were housed and handled according to approved guidelines. Brain slices were prepared from postnatal day 3 (P3) to P6 and P18 to P28 animals. Rats were anesthetized with ketamine $(100 \mathrm{mg} / \mathrm{kg})$ before decapitation. The brain was rapidly removed and submerged in oxygenated $\left(95 \% \mathrm{O}_{2} / 5 \% \mathrm{CO}_{2}\right)$ ice-cold saline with no added calcium [containing (in $\mathrm{mM}$ ): $125 \mathrm{NaCl}, 3.5$ $\mathrm{KCl}, 26 \mathrm{NaHCO}_{3}, 10 \mathrm{D}$-glucose, and $\left.4 \mathrm{MgCl}_{2}\right]$. Coronal sections $(300 \mu \mathrm{m})$ containing somatosensory cortex were cut with a Vibratome. Slices were stored in saline consisting of (in $\mathrm{mm}$ ): $125 \mathrm{NaCl}, 5 \mathrm{KCl}, 26 \mathrm{NaHCO}_{3}, 10$ D-glucose, $2.5 \mathrm{CaCl}_{2}$, and $1.3 \mathrm{MgCl}_{2}$, bubbled with $95 \% \mathrm{O}_{2} / 5 \% \mathrm{CO}_{2}$. 
Whole-cell voltage-clamp recordings were made from visually identified neocortical pyramidal cells in layer II/III. Cells were identified by their distance from the pial surface, pyramidal shape, and the presence of a prominent apical dendrite. Recordings were made at $30^{\circ} \mathrm{C}$ and at a holding potential of $-70 \mathrm{mV}$. Pipettes were pulled from $1.5 \mathrm{~mm}$ glass capillaries (KG-33; Garner Glass Company). They had resistances of 2-4 M $\Omega$ when filled with the intracellular solution. Series resistance (Rs) was carefully monitored throughout each experiment by the use of a small hyperpolarizing voltage step applied before each acquisition (see Fig. $1 A$, inset). The peak of the capacitative transient was used to estimate series resistance (equal to the instantaneous current divided by the voltage step: Rs = $\left.I_{\text {peak }} / \mathrm{V}_{\text {step }}\right)$. Only recordings with stable Rs $(<20 \mathrm{M} \Omega$ with $<5 \mathrm{M} \Omega$ change in $20 \mathrm{~min}$ ) were used in the analysis.

The internal solutions contained (in mM): $135 \mathrm{~K}$-gluconate, 5 EGTA, 10 HEPES, $2 \mathrm{MgATP}, 0.2 \mathrm{NaGTP}$, and $0.2 \mathrm{CaCl}_{2}$. $\mathrm{KCl}$ was substituted for $\mathrm{K}$-gluconate to arrive at the desired $\mathrm{Cl}^{-}$concentration. The $\mathrm{pH}$ was adjusted to 7.3 with $1 \mathrm{~mm} \mathrm{KOH}$ and $\mathrm{HCl}$ such that the final added $\mathrm{Cl}^{-}$ concentration equaled 1,20 , or $40 \mathrm{~mm}$ and the final $\left[\mathrm{K}^{+}\right]_{\mathrm{i}}$ was always 150 mM. Sucrose was added to achieve a final osmolarity of $300 \mathrm{mOsm}$. Liquid junction potentials for all solutions were measured, and all voltages reported are corrected values (Neher, 1992).

During recording, slices were continuously perfused with the storage saline listed above with the addition of $0.5 \mu \mathrm{M}$ TTX (Calbiochem) to block $\mathrm{Na}^{+}$-dependent action potentials, $2-5 \mathrm{~mm}$ kynurenic acid (Tocris) to block ionotropic glutamate receptors, and $10 \mu \mathrm{M}$ SCH50911 (Research Biochemicals, Natick, MA) to antagonize $\mathrm{GABA}_{\mathrm{B}}$ receptors. Extracellular $\mathrm{K}^{+}$was varied by making $\mathrm{K}^{+}$-free saline and adding $1,3.5$, or $10 \mathrm{mM} \mathrm{KCl}$ Saline containing $1 \mathrm{~mm}$ furosemide was sonicated for $30 \mathrm{~min}$ and then oxygenated for at least $30 \mathrm{~min}$ before bath application. All drugs (except GABA) were bath applied, and each cell served as its own control. Bath temperature was maintained at $30^{\circ} \mathrm{C}$ by the use of an in-line heating unit (Warner Instruments). Whole-cell and excised patch recordings (Sakmann and Neher, 1995) were made with an Axopatch-1B amplifier. No series resistance compensation was used. Recordings were digitized at $5-10 \mathrm{kHz}$ by the use of a Digidata 1200 data acquisition system and Clampex software (Axon Instruments). Data analysis was performed with custom scripts written for Origin Pro (Microcal Software). All averages are reported as the mean \pm SEM. A Student's $t$ test was used to determine significance $(p<0.05)$.

Pressure application of $G A B A$. Under direct visual guidance, GABA (250 $\mu \mathrm{M}$ or $1 \mathrm{mM}$ ) was pressure applied to the soma of the recorded neuron or to excised patches. Pipettes for pressure applications were fabricated in the same manner as patch electrodes described above. GABA was applied in a solution consisting of (in $\mathrm{mM}$ ): $125 \mathrm{NaCl}, 3.5 \mathrm{KCl}, 20 \mathrm{HEPES}$, and 10 glucose; $\mathrm{pH}$ is 7.3 with $\mathrm{NaOH}$. Pressure applications were controlled by the use of a Picospritzer II (General Valve, Fairfield, NJ). Pulses of 5-15 msec were delivered at 3-12 psi. These settings were kept constant during recording. Application of the pressure pipette solution without GABA did not evoke a detectable current $(n=3)$.

Reverse transcription-PCR. The methods used for determination of mRNA in single neurons have been described (Poth et al., 1997; Devay et al., 1999). In brief, cytoplasm and pipette solution $(\sim 6 \mu \mathrm{l})$ were reverse transcribed in a $20 \mu \mathrm{l}$ reaction $\left(1 \mathrm{hr}\right.$ at $\left.37^{\circ} \mathrm{C}\right)$ containing $1 \mathrm{mM}$ each dNTP 100 pmol of 18-mer polyT, $20 \mathrm{U}$ of RNase inhibitor, and $40 \mathrm{U}$ of AMV reverse transcriptase. Sets of specific primers were constructed such that the annealed products crossed at least one intron/exon boundary, excluding the possibility of amplification of genomic DNA. PCR reactions $(50 \mu \mathrm{l})$ contained aliquots of the reverse transcriptase (rt) product, $1 \mathrm{~mm}$ dNTPs, $2.5 \mathrm{mM} \mathrm{MgCl}_{2}, 10 \mathrm{pmol}$ of each forward and reverse primer, and $5 \mathrm{U}$ of Taq polymerase. The PCR cycling parameters were as follows: 5 cycles of $94^{\circ} \mathrm{C}$ for $1 \mathrm{~min}, 55^{\circ} \mathrm{C}$ for $1 \mathrm{~min}$, and $72^{\circ} \mathrm{C}$ for 2 min followed by 35 cycles of $94^{\circ} \mathrm{C}$ for $1 \mathrm{~min}, 65^{\circ} \mathrm{C}$ for $1 \mathrm{~min}$, and $72^{\circ} \mathrm{C}$ for $2 \mathrm{~min}$. The reaction products were then spun through CentriSep columns to remove excess primers and subjected to reamplification (one or two additional amplification steps) by the use of 35 cycles of $94^{\circ} \mathrm{C}$ for $1 \mathrm{~min}, 65^{\circ} \mathrm{C}$ for $1 \mathrm{~min}$, and $72^{\circ} \mathrm{C}$ for $2 \mathrm{~min}$. Final reaction products were purified by phenol/chloroform extraction. The PCR products were subjected to analysis on $2 \%$ agarose gels. rt-PCR was performed without knowledge of the age of the animal or the contents of each centrifuge tube (control extracellular solution or intracellular harvest).

The primers for the experiments were as follows: actin (GenBank accession number L08165) sense, ATCTTTCTTGGGTATGGA, and antisense, ACATCTGCTGGAAGGTGG; KCC2 (GenBank accession number AJ011033) sense, GCAGAGAGTACGATGGCAGG, and antisense, CGTGCCAAGGATGTACATAGC

Intracellular chloride calculation. $\left[\mathrm{Cl}^{-}\right]_{\mathrm{i}}$ was calculated from the reversal potential of GABA-evoked currents. Cells were voltage-clamped to -70 $\mathrm{mV}$ and stepped to various test potentials. The series resistance (estimated from the peak transient during a $10 \mathrm{mV}$ test pulse given before each trial) and the amplitude of the current (before baseline correction, see Fig. $1 A$, inset ) 100-200 msec from the time of the pressure application were used to calculate the voltage error caused by uncorrected series resistance errors. The baseline current (taken $20 \mathrm{msec}$ before the time of the pressure pulse) was subtracted from the absolute current amplitude (see Fig. $1 \mathrm{~A}$, baselinecorrected traces). These values were plotted as a function of the series resistance-corrected membrane potential (see Fig. $1 B$ ). The three consecutive data points whose sum was closest to zero current were selected for a linear fit. The $x$-axis intercept $(y=0)$ of this fit was verified by eye and referred to throughout this paper as the reversal potential $\left(\mathrm{V}_{\text {rev }}\right) \cdot\left[\mathrm{Cl}^{-}\right]_{\mathrm{i}}$ was calculated from the reversal potential by the use of a derivation from the Nernst equation:

$$
\left[\mathrm{Cl}^{-}\right]_{\text {in }}=\left[\mathrm{Cl}^{-}\right]_{\text {out }} \exp \left(-V_{\text {rev }} F / R T\right) .
$$

$\left[\mathrm{Cl}^{-}\right]_{\mathrm{o}}$ was set to the extracellular $\mathrm{Cl}^{-}$concentration, corrected for activity (Robinson and Stokes, 1959) (e.g., in $3.5 \mathrm{~mm}\left[\mathrm{~K}^{+}\right]_{\mathrm{o}}, 139.6 \mathrm{mM} \times$ $76 \%=106.1 \mathrm{mM})$. Averaged changes in reversal potential and $\left[\mathrm{Cl}^{-}\right]$ reflect the mean of the differences from the control condition $(3.5 \mathrm{~mm}$ $\left[\mathrm{K}^{+}\right]_{\mathrm{o}}$ ) for each cell; thus, each cell served as its own control.

The role of bicarbonate and other anions. Bicarbonate is known to permeate $\mathrm{GABA}_{\mathrm{A}}$ receptors (Bormann et al., 1987). We did not account for a bicarbonate component of the $\mathrm{GABA}_{\mathrm{A}}$ current because our results suggest that bicarbonate does not contribute significantly to the whole-cell currents under our recording conditions. When $1 \mathrm{mM} \mathrm{Cl}^{-}$was included in the pipette, the reversal potential of $\mathrm{GABA}_{\mathrm{A}}$-mediated currents was depolarized relative to the reversal potential obtained in excised patches (see Fig. 2A). This result is consistent with a bicarbonate efflux caused by 20 $\mathrm{mm}$ intracellular bicarbonate and a permeability ratio of $1: 5\left(\mathrm{HCO}_{3}^{-} / \mathrm{Cl}^{-}\right)$. However, lowering $\left[\mathrm{K}^{+}\right]_{\mathrm{o}}$ and cotransport antagonism with furosemide both lowered the reversal potential to values similar to those obtained in excised patches (see Results). Because these types of manipulations are not expected to affect intracellular bicarbonate, changes in $V_{\text {rev }}$ are attributed to alterations in $\mathrm{Cl}^{-}$and $\mathrm{K}^{+}-\mathrm{Cl}^{-}$cotransport

Another source of error was the purity of the compound providing the primary anion in the internal solution. We obtained potassium-Dgluconate, "puriss" grade, from Fluka. Other sources of the potassium salts of isethionate (Eastman Kodak) and methylsulfate (J. T. Baker Chemical Company) resulted in reversal potential measurements indicative of 10-15 $\mathrm{mm}$ internal $\mathrm{Cl}^{-}$when no $\mathrm{Cl}^{-}$had been added to the pipette solution. This suggests that these compounds were contaminated with significant amounts of chloride (or another substance permeable through $\mathrm{GABA}_{\mathrm{A}}$ receptors). It has also been reported that gluconate can pass through $\mathrm{GABA}_{\mathrm{A}}$ channels (Barker and Harrison, 1988). Our results with excised patches demonstrated an effective concentration of pipette $\mathrm{Cl}^{-}$of $2.06 \pm$ $0.16 \mathrm{~mm}$ when only $1 \mathrm{~mm} \mathrm{KCl}$ was added. Assuming that this difference from added $\mathrm{Cl}^{-}$is caused solely by gluconate permeability, the relative permeability of gluconate to $\mathrm{Cl}^{-}$is $\sim 0.008$.

\section{RESULTS}

\section{Disparity between pipette chloride and calculated intracellular chloride}

We assessed the intracellular $\mathrm{Cl}^{-}$concentration of neocortical pyramidal neurons by measuring the reversal potential of $\mathrm{GABA}_{\mathrm{A}}$ receptor-mediated currents. Responses to pressure application of $250 \mu \mathrm{M}$ GABA are shown in Figure $1 A$. The pipette $\mathrm{Cl}^{-}$concentration was $1 \mathrm{~mm}$ in this recording. The inset illustrates the currents evoked by the voltage step protocol and local pressure application of GABA. The currents are shown superimposed on a faster time base after zeroing the baseline currents. GABA response amplitude was measured 100-200 msec after the pressure pulse, at the time indicated by the vertical dotted line. Response amplitude is plotted as a function of membrane potential in Figure $1 B$ (squares). After correction for the series resistance error (circles), the reversal potential was calculated from a linear fit to the three consecutive data points closest to zero current (dotted line). This indicated a $\mathrm{V}_{\text {rev }}$ of $-89.9 \mathrm{mV},>30 \mathrm{mV}$ depolarized from the expected value of $-121 \mathrm{mV}$ calculated for $1 \mathrm{~mm}\left[\mathrm{Cl}^{-}\right]_{\mathrm{i}}$.

The observed discrepancy in $\mathrm{V}_{\text {rev }}$ implies the existence of a homeostatic mechanism that regulates $\left[\mathrm{Cl}^{-}\right]_{\mathrm{i}}$. To test this hypothesis and to determine whether such a mechanism is developmentally regulated, measurements of $\mathrm{V}_{\text {rev }}$ were made in P3-P6 and $\mathrm{P} 18-\mathrm{P} 28$ animals at various pipette $\mathrm{Cl}^{-}$concentrations. Reversal potentials determined for each of these experimental conditions, at a $\left[\mathrm{K}^{+}\right]_{\mathrm{o}}$ of $3.5 \mathrm{~mm}$, are shown in Figure $2 \mathrm{~A}$. The mean reversal potentials for the three pipette chloride concentrations are shown for recordings from P18 to P28 (white circles) and P3 to P6 (gray triangles) neurons. This plot also shows the theoretical relationship between $\left[\mathrm{Cl}^{-}\right]_{\mathrm{i}}$ and the reversal potential (solid line). In whole-cell recordings with $1 \mathrm{~mm}$ pipette chloride, the reversal potential in both P3-P6 and P18-P28 neurons was always more depolarized than the value predicted from the Nernst equation. This implies the existence of a $\mathrm{Cl}^{-}$accumulation mechanism in both groups. At higher pipette chloride concentrations (20 and $40 \mathrm{~mm}$ ) the measured reversal potential was consistently below the predicted reversal potential, consistent with a $\mathrm{Cl}^{-}$extrusion mechanism. 

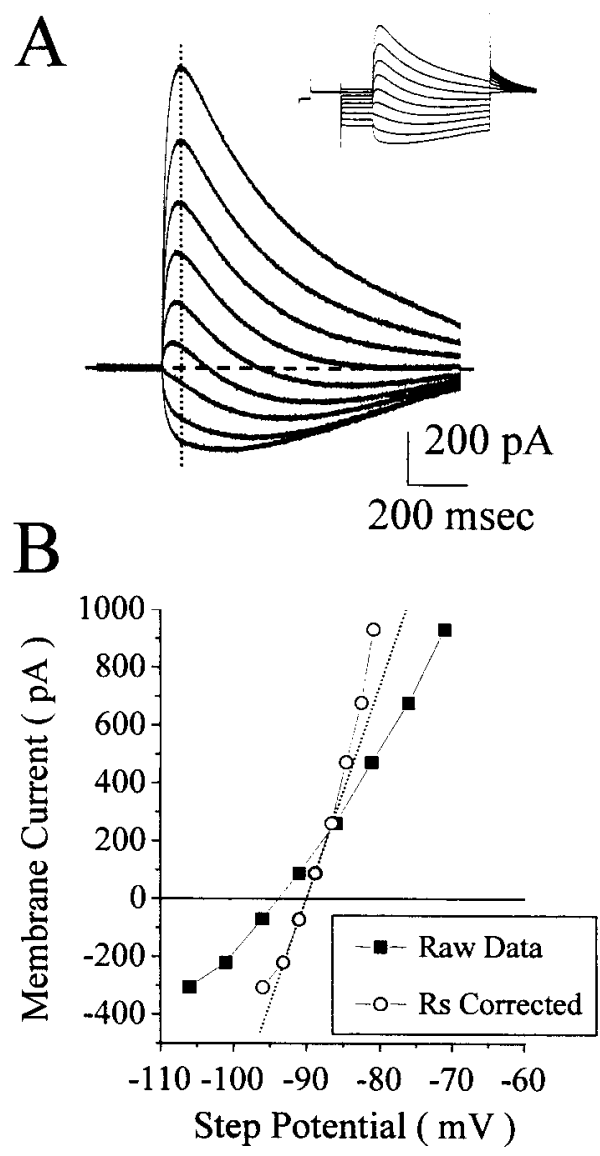

Figure 1. The reversal potential of the GABA-evoked current measured from the amplitudes of the responses at different step potentials. $A$, The baseline current at each step potential was subtracted from the raw traces (shown in the inset). B, Then the amplitude of the current at the vertical dotted line in $A$ was plotted as a function of step potential. Squares illustrate the amplitudes as a function of the command potential. Circles represent current amplitude versus membrane potential corrected for the series resistance $(R s)$ error. A linear fit (dotted line) to the current as a function of the $R s$-corrected step potential was obtained from the three consecutive data points closest to zero current (gray circles). This recording was obtained from a $\mathrm{P} 18-\mathrm{P} 28$ neuron with $1 \mathrm{~mm}$ pipette $\mathrm{Cl}^{-}$.

We also estimated reversal potentials in excised patches, reasoning that the large volume of the pipette solution should minimize the effects of $\mathrm{Cl}^{-}$homeostatic mechanisms residing in the small patch of membrane in the pipette tip. The reversal potentials from excised patches were closer to values calculated from the expected pipette $\left[\mathrm{Cl}^{-}\right]$than to those obtained in whole-cell recordings, as shown in Figure $2 A$ (black squares). Also, the reversal potentials in excised patches were insensitive to manipulations that effected KCC2 function in whole-cell recordings (changes in $\left[\mathrm{K}^{+}\right]_{\mathrm{o}}$ and furosemide; data not shown). These data support the existence of homeostatic $\left[\mathrm{Cl}^{-}\right]_{\mathrm{i}}$ regulation involving a $\mathrm{Cl}^{-}$accumulation mechanism at low pipette $\mathrm{Cl}^{-}$concentrations and a $\mathrm{Cl}^{-}$extrusion mechanism when pipette $\mathrm{Cl}^{-}$is elevated.

Figure $2 \mathrm{~B}$ plots the calculated $\left[\mathrm{Cl}^{-}\right]_{\mathrm{i}}$ for each group when the pipette contained $1 \mathrm{mM} \mathrm{Cl}^{-}$. In $\mathrm{P} 18-\mathrm{P} 28$ neurons, $\left[\mathrm{Cl}^{-}\right]_{\mathrm{i}}$ was $3.73 \pm 0.35 \mathrm{~mm}(n=11)$, whereas it was significantly lower in P3-P6 cells (2.82 \pm 0.16 mM; $p<0.04 ; n=5)$. Recordings from excised patches indicated a pipette $\mathrm{Cl}^{-}$concentration of $2.10 \pm$ $0.16 \mathrm{~mm}(n=4)$. Estimates of $\left[\mathrm{Cl}^{-}\right]_{\mathrm{i}}$ in P3-P6 and P18-P28 neurons were significantly greater than that in excised patches $(p<$ 0.03 ). If we assume that the reversal potential of currents in excised patches with $1 \mathrm{~mm}$ pipette $\mathrm{Cl}^{-}$reflects the actual pipette $\mathrm{Cl}^{-}$ concentration, these results suggest that in $3.5 \mathrm{~mm}\left[\mathrm{~K}^{+}\right]_{\mathrm{o}}$ and with low pipette $\mathrm{Cl}^{-}, \mathrm{P} 3-\mathrm{P} 6$ and $\mathrm{P} 18-\mathrm{P} 28$ neurons can accumulate $0.7-1.6 \mathrm{mM} \mathrm{Cl}^{-}$.
A

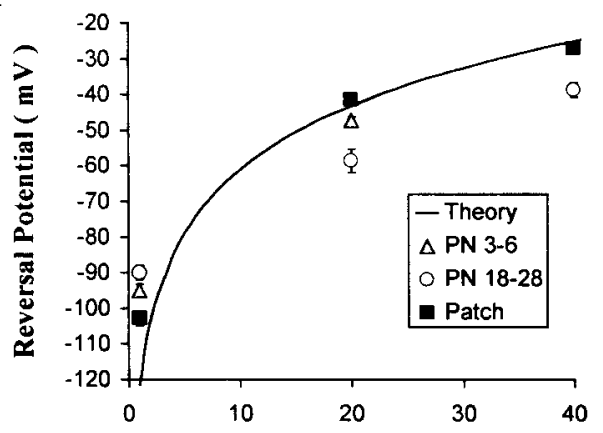

Pipette Chloride Concentration ( $\mathrm{mM}$ )

B

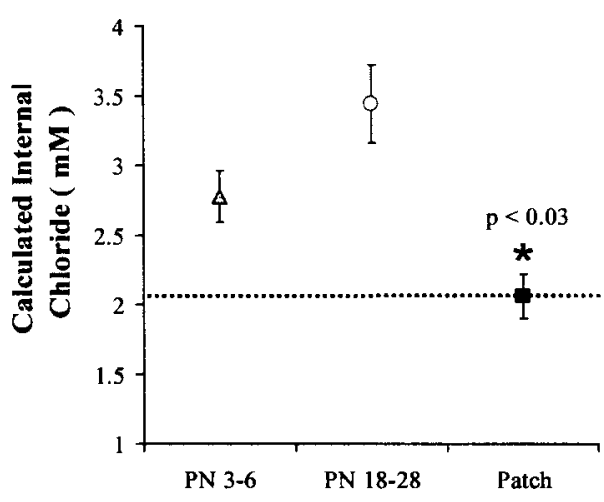

1 mM Pipette Chloride

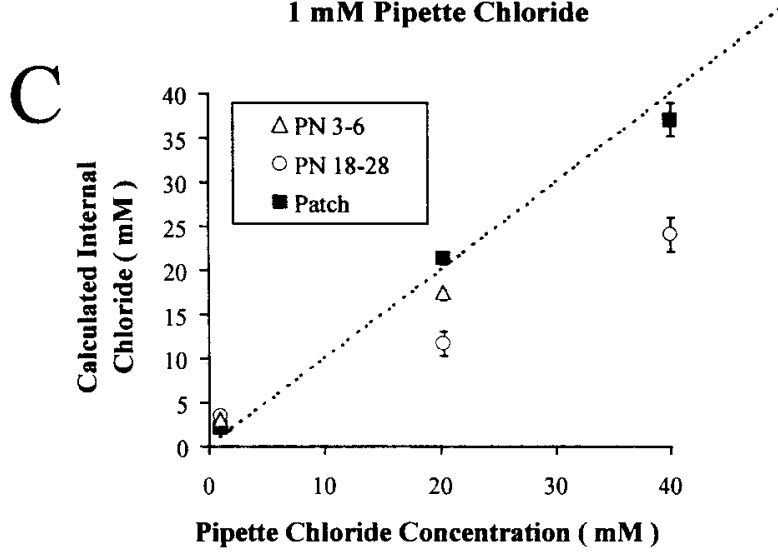

Figure 2. Reversal potentials for $\mathrm{GABA}_{\mathrm{A}}$ currents recorded with different pipette $\mathrm{Cl}^{-}$concentrations support $\mathrm{Cl}^{-}$accumulation and extrusion in neocortical pyramidal cells. $A$, Reversal potentials obtained at three pipette $\mathrm{Cl}^{-}$concentrations in postnatal days 3-6 (PN 3-6), $P N 18-28$, and outsideout patches are plotted as a function of pipette $\mathrm{Cl}^{-}$concentration. For comparison, the theoretical relationship between $\left[\mathrm{Cl}^{-}\right]_{\mathrm{i}}$ and reversal potential (assuming $103.4 \mathrm{~mm}\left[\mathrm{Cl}^{-}\right]_{\mathrm{o}}$ ) is shown as a solid line. Reversal potentials obtained from outside-out patches were closest to theoretical. The reversal potentials from $P N$ 3-6 and $P N$ 18-28 were significantly different from outside-out patches at all pipette $\mathrm{Cl}^{-}$concentrations $(p<$ $0.03)$. $B$, Mean calculated $\left[\mathrm{Cl}^{-}\right]_{\mathrm{i}}$ was significantly lower in outside patches $*)(p<0.03)$ and $1.1 \mathrm{~mm}$ higher than the added $\mathrm{KCl}$ concentration $(1$ $\mathrm{mM})$. The differences in whole-cell $\left[\mathrm{Cl}^{-}\right]_{\mathrm{i}}$ from the excised patch values suggest a $\mathrm{Cl}^{-}$accumulation mechanism in both neonatal and $P N 18-28$ neurons. $C$, Calculated $\left[\mathrm{Cl}^{-}\right]_{\mathrm{i}}$ is plotted as a function of pipette $\mathrm{Cl}^{-}$ concentration. As in $A$ both $P N 3-6$ and $P N 18-28$ neurons had significantly lower calculated $\left[\mathrm{Cl}^{-}\right]_{\mathrm{i}}$ compared with that in excised patches, suggesting the action of a $\mathrm{Cl}^{-}$extrusion mechanism.

Figure $2 C$ plots the calculated $\left[\mathrm{Cl}^{-}\right]_{\mathrm{i}}$ as a function of pipette chloride concentration. In $3.5 \mathrm{~mm}\left[\mathrm{~K}^{+}\right]_{\mathrm{o}}$ and elevated pipette $\mathrm{Cl}^{-}$, the reversal potentials of whole-cell currents evoked by GABA were consistently lower than the expected values calculated from the Nernst equation. They were also lower than the values obtained 


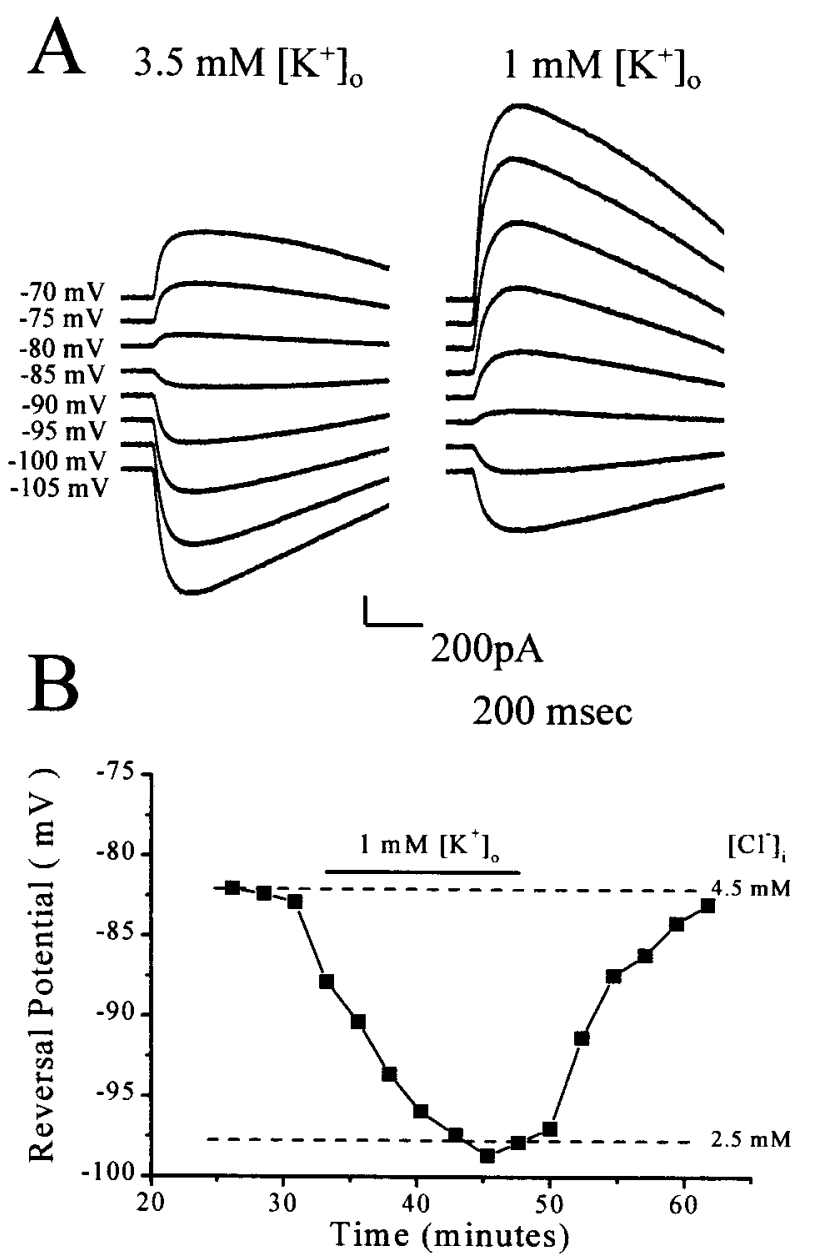

Figure 3. Lowering extracellular potassium lowers intracellular chloride. $A$, GABA $(250 \mu \mathrm{M})$ was applied at $20 \mathrm{sec}$ intervals to the soma during voltage steps to the indicated potentials. The pipette solution contained 1 $\mathrm{mm}$ added $\mathrm{Cl}^{-}$. Relative to the currents evoked by GABA application in 3.5 $\mathrm{mM}\left[\mathrm{K}^{+}\right]_{\mathrm{o}}$, a $15 \mathrm{mV}$ drop in the reversal potential is apparent. $B$, A time course plot of the change in reversal potential is shown.

in outside-out patches. With $20 \mathrm{~mm}$ pipette $\mathrm{Cl}^{-}$, the calculated $\left[\mathrm{Cl}^{-}\right]_{\mathrm{i}}$ in P3-P6 neurons was $17.55 \pm 0.71 \mathrm{~mm}(n=5)$, whereas in P18-P28 neurons, $\left[\mathrm{Cl}^{-}\right]_{\mathrm{i}}$ was significantly lower $(11.9 \pm 1.1 \mathrm{~mm}$; $p<0.002 ; n=11) .\left[\mathrm{Cl}^{-}\right]_{\mathrm{i}}$ determined in excised patches was significantly higher than that in either P3-P6 or P18-P28 neurons (21.69 $\pm 0.72 \mathrm{~mm} ; n=7 ; p<0.005)$. Assuming that the reversal potential in excised patches reflects the actual pipette $\mathrm{Cl}^{-}$concentration, our results imply that the neuronal $\mathrm{Cl}^{-}$homeostatic mechanisms can extrude $4-9 \mathrm{mM} \mathrm{Cl}^{-}$in $3.5 \mathrm{~mm}\left[\mathrm{~K}^{+}\right]_{\mathrm{o}}$. These data support a prominent role for $\mathrm{Cl}^{-}$extrusion in determining $\left[\mathrm{Cl}^{-}\right]_{\mathrm{i}}$ in these neurons.

\section{Alterations in $\left[\mathrm{K}^{+}\right]_{0}$ affect $\left[\mathrm{Cl}^{-}\right]_{\mathrm{i}}$}

If $\mathrm{K}^{+}$-coupled $\mathrm{Cl}^{-}$cotransport is involved in the accumulation and extrusion of $\mathrm{Cl}^{-}$demonstrated above, manipulations of $\left[\mathrm{K}^{+}\right]_{\mathrm{o}}$ should change the reversal potential of the GABA-evoked currents. Lowering $\left[\mathrm{K}^{+}\right]_{\mathrm{o}}$ should lower the $\mathrm{Cl}^{-}$set point and thus enhance extrusion and/or retard accumulation. Raising $\left[\mathrm{K}^{+}\right]_{\mathrm{o}}$ should have the opposite effect by raising the $\mathrm{Cl}^{-}$set point via impairment of extrusion and/or enhancement of accumulation.

Figure 3 illustrates the effect of decreasing $\left[\mathrm{K}^{+}\right]_{\mathrm{o}}$ on whole-cell responses to GABA. The recordings were obtained from a P18P28 neuron by the use of $1 \mathrm{mM} \mathrm{Cl}^{-}$in the recording pipette. GABA responses in 3.5 and $1 \mathrm{~mm}\left[\mathrm{~K}^{+}\right]_{\mathrm{o}}$ are shown in Figure $3 A$. At a holding potential of $-85 \mathrm{mV}$, the GABA-evoked current changes from inward to outward when the $\left[\mathrm{K}^{+}\right]_{\mathrm{o}}$ was changed from 3.5 to $1 \mathrm{~mm}$. Lowering $\left[\mathrm{K}^{+}\right]_{\mathrm{o}}$ consistently shifted the reversal

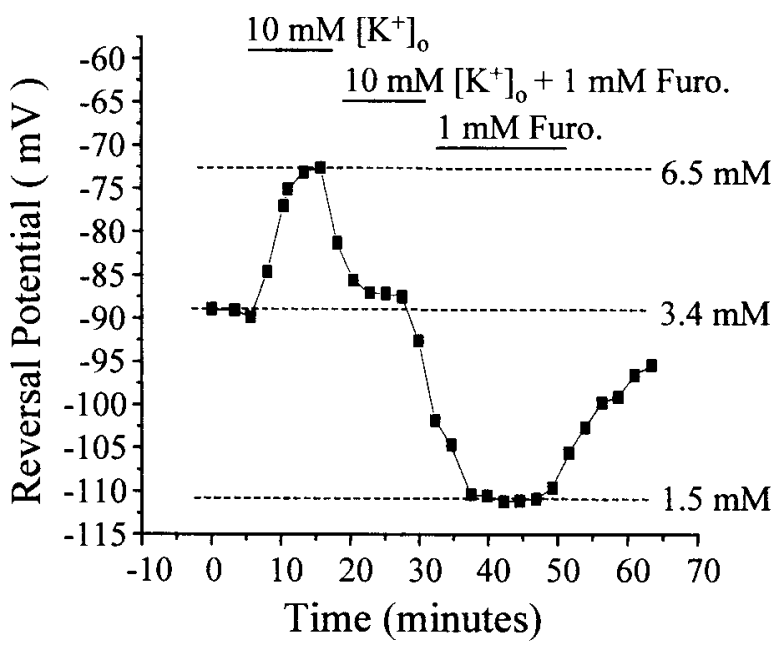

Figure 4. Potassium and furosemide alter intracellular chloride. A $10 \mathrm{~min}$ application of $10 \mathrm{mM}\left[\mathrm{K}^{+}\right]_{\mathrm{o}}$ reversibly depolarized the reversal potential and raised the $\left[\mathrm{Cl}^{-}\right]$by $3.1 \mathrm{~mm}$. After washout, bath application of $1 \mathrm{~mm}$ furosemide hyperpolarized the reversal potential and lowered $\left[\mathrm{Cl}^{-}\right]_{\mathrm{i}}$ by 1.9 $\mathrm{mM}$. In this figure, 0 min represents the first current-voltage measurement taken $\sim 5$ min after whole-cell mode was achieved. Furo., Furosemide.

potential in the negative direction, indicating a decrease in $\left[\mathrm{Cl}^{-}\right]_{\mathrm{i}}$. In whole-cell recordings from P18 to P28 neurons with $1 \mathrm{~mm}$ pipette $\mathrm{Cl}^{-}$, the mean reversal potential $(-100.1 \pm 1.3 \mathrm{mV} ; n=5)$ and calculated $\left[\mathrm{Cl}^{-}\right]_{\mathrm{i}}(2.27 \pm 0.11 \mathrm{~mm})$ measured in $1 \mathrm{~mm}\left[\mathrm{~K}^{+}\right]_{\mathrm{o}}$ were not significantly different from the mean values obtained in outside-out patches $(-102.8 \pm 2.0 \mathrm{mV}$ and $2.06 \pm 0.16 \mathrm{~mm}$, respectively; $p>0.3)$. This difference was significant $(p<0.002)$ in 3.5 and $10 \mathrm{~mm}\left[\mathrm{~K}^{+}\right]_{0}$. The change in reversal potential occurred slowly and was reversible, as shown in Figure $3 B$.

In previous studies, raising extracellular potassium inhibited $\mathrm{Cl}^{-}$ extrusion (Thompson et al., 1988a,b; Thompson and Gähwiler, 1989 b). Payne (1997) estimated the apparent affinity $\left(K_{\mathrm{m}}\right)$ of KCC2 for $\left[\mathrm{K}^{+}\right]_{\mathrm{o}}$ to be $\sim 5 \mathrm{~mm}$. This led to the hypothesis that KCC2 could operate in reverse in the presence of elevated $\left[\mathrm{K}^{+}\right]_{\mathrm{o}}$ and accumulate both $\mathrm{K}^{+}$and $\mathrm{Cl}^{-}$. As shown in Figure 4 , raising $\left[\mathrm{K}^{+}\right]_{0}$ reversibly shifted the reversal potential in the depolarizing direction. In these experiments, the cell was initially maintained in 3.5 $\mathrm{mm}\left[\mathrm{K}^{+}\right]_{\mathrm{o}}$. The bath concentration of $\mathrm{K}^{+}$was then raised to $10 \mathrm{~mm}$, resulting in a $>15 \mathrm{mV}$ depolarization in the reversal potential. This indicates a corresponding $3.1 \mathrm{~mm}$ increase in $\left[\mathrm{Cl}^{-}\right]_{\mathrm{i}}$. With low pipette $\mathrm{Cl}^{-}$, raising $\left[\mathrm{K}^{+}\right]_{\mathrm{o}}$ increased $\left[\mathrm{Cl}^{-}\right]_{\mathrm{i}}$ by increasing the net influx of $\mathrm{Cl}^{-}$via $\mathrm{K}^{+}-\mathrm{Cl}^{-}$cotransport.

Furosemide is a loop diuretic that blocks chloride cotransport. Application of furosemide in the presence of $10 \mathrm{~mm}\left[\mathrm{~K}^{+}\right]_{0}$ shifted the reversal potential back toward initial levels (Fig. 4). Lowering $\left[\mathrm{K}^{+}\right]_{\mathrm{o}}$ to $3.5 \mathrm{~mm}$ in the presence of furosemide made the reversal potential more negative (Fig. 4), approaching levels observed with excised patches. This effect was reversible. In furosemide and $1 \mathrm{~mm}$ pipette $\mathrm{Cl}^{-}$, both the reversal potential $(-93.5 \pm 6.8 \mathrm{mV} ; n=4,4$ animals) and the calculated $\left[\mathrm{Cl}^{-}\right]_{\mathrm{i}}(3.19 \pm 0.72 \mathrm{~mm})$ were not significantly different from the same parameters recorded in outside-out patches $(p>0.2)$. This effect is similar to the lowering of $\left[\mathrm{Cl}^{-}\right]_{\mathrm{i}}$ observed in $1 \mathrm{~mm}\left[\mathrm{~K}^{+}\right]_{\mathrm{o}}$. The combination of these results suggests that the $\mathrm{Cl}^{-}$accumulation mechanism responsible for the deviations from low pipette $\mathrm{Cl}^{-}$concentrations is a $\mathrm{K}^{+}$-coupled $\mathrm{Cl}^{-}$cotransporter.

To test the hypothesis that $\mathrm{K}^{+}$-coupled $\mathrm{Cl}^{-}$extrusion lowers $\left[\mathrm{Cl}^{-}\right]_{\mathrm{i}}$ in recordings with elevated pipette $\mathrm{Cl}^{-}$, we examined the effects of manipulating $\left[\mathrm{K}^{+}\right]_{\mathrm{o}}$ and blocking transport with furosemide. Figure $5 A$ summarizes the effects of manipulating $\left[\mathrm{K}^{+}\right]_{0}$ and furosemide application on reversal potentials in P18-P28 neurons. The changes in $\left[\mathrm{Cl}^{-}\right]_{\mathrm{i}}$ are shown in Figure $5 B$. When recordings were made with $1 \mathrm{~mm}$ pipette $\mathrm{Cl}^{-}$, lowering $\left[\mathrm{K}^{+}\right]_{\mathrm{o}}$ to $1 \mathrm{~mm}$ produced a $-12.7 \pm 2.3 \mathrm{mV}(n=5)$ change in reversal potential, 

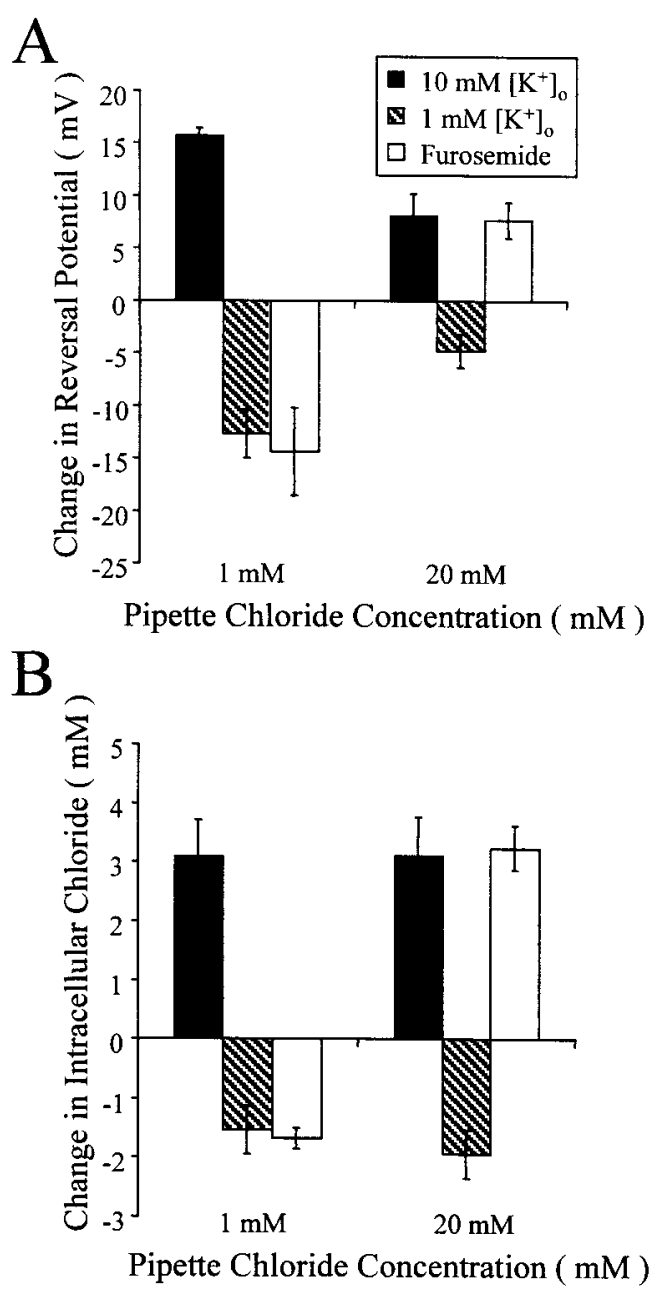

Figure 5. The action of furosemide depends on pipette chloride. $A$, Changes in reversal potential were smaller in $20 \mathrm{~mm}$ pipette $\mathrm{Cl}^{-}$but resulted in similar changes in calculated $\left[\mathrm{Cl}^{-}\right]_{\mathrm{i}} . B$, Furosemide lowered the reversal potential and $\left[\mathrm{Cl}^{-}\right]_{\mathrm{i}}$ when pipette $\mathrm{Cl}^{-}$was low and raised both the reversal potential and $\left[\mathrm{Cl}^{-}\right]_{\mathrm{i}}$ when pipette $\mathrm{Cl}^{-}$was high. The magnitude of the effect of furosemide was not significantly different from that of the effect of lowering $\left[\mathrm{K}^{+}\right]_{\mathrm{o}}$ in $1 \mathrm{~mm}$ pipette $\mathrm{Cl}^{-}$or raising $\left[\mathrm{K}^{+}\right]_{\mathrm{o}}$ in $20 \mathrm{~mm}$ pipette $\mathrm{Cl}^{-}$.

indicating a $1.54 \pm 0.41 \mathrm{~mm}$ decrease in $\left[\mathrm{Cl}^{-}\right]_{\mathrm{i}}$. A similar change in both parameters was observed with $20 \mathrm{~mm}$ pipette $\mathrm{Cl}^{-}$. Likewise, the mean changes in reversal potential and calculated $\left[\mathrm{Cl}^{-}\right]_{\mathrm{i}}$ when $\left[\mathrm{K}^{+}\right]_{\mathrm{o}}$ was raised to $10 \mathrm{~mm}$ were similar in both 1 and $20 \mathrm{~mm}$ pipette $\mathrm{Cl}^{-}$groups. The effect of furosemide depended on the pipette $\mathrm{Cl}^{-}$ concentration. In $1 \mathrm{~mm}$ pipette $\mathrm{Cl}^{-}$, furosemide shifted the reversal potential to more negative values and lowered calculated $\left[\mathrm{Cl}^{-}\right]_{\mathrm{i}}$. In the $20 \mathrm{~mm}$ pipette $\mathrm{Cl}^{-}$group, furosemide produced a positive shift in the reversal and raised the calculated $\left[\mathrm{Cl}^{-}\right]_{\mathrm{i}}$.

The dependency of the action of furosemide on pipette $\mathrm{Cl}^{-}$ supports the hypothesis that $\mathrm{Cl}^{-}$homeostatic mechanisms can operate either to accumulate or to extrude $\mathrm{Cl}^{-}$. In $10 \mathrm{~mm}\left[\mathrm{~K}^{+}\right]_{\mathrm{o}}$ the reversal potential and calculated $\left[\mathrm{Cl}^{-}\right]_{\mathrm{i}}$ were still significantly lower than those obtained with outside-out patches $(p<0.002 ; n=$ $5 ; 20 \mathrm{~mm}\left[\mathrm{Cl}^{-}\right]$pipette; $n=3 ; 40 \mathrm{~mm}\left[\mathrm{Cl}^{-}\right]$pipette $)$. This suggests that although $\mathrm{K}^{+}-\mathrm{Cl}^{-}$cotransport plays an important role in maintaining $\left[\mathrm{Cl}^{-}\right]_{\mathrm{i}}$, other mechanisms may also contribute to $\mathrm{Cl}^{-}$extrusion.

\section{Developmental regulation of KCC2 function and expression}

Previous studies have indicated that KCC2 expression is developmentally regulated (Lu et al., 1999; Rivera et al., 1999). We tested the hypothesis that the reversal potential of $\mathrm{Cl}^{-}$currents in neurons lacking $\mathrm{KCC} 2$ would be relatively insensitive to changes in
$\left[\mathrm{K}^{+}\right]_{\mathrm{o}}$. Figure $6 A$ shows the lack of effect of changes in $\left[\mathrm{K}^{+}\right]_{\mathrm{o}}$ on the $\mathrm{Cl}^{-}$reversal potential in a P3 animal. The reversal potential immediately after establishment of whole-cell recording with 20 $\mathrm{mm}$ pipette $\mathrm{Cl}^{-}$reached a value near $-49 \mathrm{mV}$. Only minimal changes in the reversal potential were subsequently observed. In P3-P6 neurons, neither raising $\left[\mathrm{K}^{+}\right]_{\mathrm{o}}$ to $10 \mathrm{mM}(n=3)$ nor lowering $\left[\mathrm{K}^{+}\right]_{\mathrm{o}}$ to $1 \mathrm{~mm}(n=3)$ had any significant effect on the reversal potential for GABA responses (Fig. 6B), consistent with a lack of expression of KCC2. Comparison of the reversal potentials in $3.5 \mathrm{~mm}\left[\mathrm{~K}^{+}\right]_{\mathrm{o}}$ between $\mathrm{P} 3-\mathrm{P} 6$ and $\mathrm{P} 18-\mathrm{P} 28$ neurons provides further support for reduced function of $\mathrm{KCC} 2$ in neonates. As shown above in Figure $2 A$, the reversal potential and $\left[\mathrm{Cl}^{-}\right]_{\mathrm{i}}$ in $\mathrm{P} 3-\mathrm{P} 6$ neurons were significantly different from that in $\mathrm{P} 18-\mathrm{P} 28$ cells, although both groups were also significantly different from the measurements made in outside-out patches $(p<0.03)$. Under conditions that support $\mathrm{Cl}^{-}$accumulation by $\mathrm{KCC} 2$ (low pipette $\mathrm{Cl}^{-}$), the reversal potential and $\left[\mathrm{Cl}^{-}\right]_{\mathrm{i}}$ in the $\mathrm{P} 3-\mathrm{P} 6$ group were significantly lower than that in $\mathrm{P} 18-\mathrm{P} 28$ neurons $(p<0.05)$. Conversely, with elevated pipette $\mathrm{Cl}^{-}$, these values were significantly higher in P3-P6 than in the older neurons $(p<0.002)$. These results suggest that KCC2 does not substantially contribute to $\mathrm{Cl}^{-}$homeostasis in $\mathrm{P} 3-\mathrm{P} 6$ neocortical neurons.

The physiological data presented above are consistent with a developmental role of KCC2 in chloride homeostasis and suggest the hypothesis that KCC2 expression levels will be reduced in P3 neurons compared with P25 neurons. To test this hypothesis, we examined KCC2 mRNA levels in P3 and P25 neurons using singlecell rt-PCR procedures (Fig. $6 C$ ). KCC2 mRNA was detected in all P25 neurons including pyramidal cells and interneurons. However, only one of four P3 neurons showed detectable levels of KCC2 mRNA. The presence of KCC2 in all P25 cells was unlikely to be caused by contamination during the rt-PCR procedure because control samples in which the cell cytoplasm was not harvested failed to reveal KCC2 mRNA expression. To ensure that the lack of KCC2 mRNA expression in P3 neurons was not caused by a failure to detect all mRNAs during the rt-PCR process, we examined, in the same sample, the expression of actin mRNA (Fig. 6D). Actin mRNA was detected in all P3 and P25 cells. The actin controls also allowed for the semiquantitative analysis of $\mathrm{KCC} 2$ levels in the one P3 neuron expressing KCC2 mRNA. The amount of KCC2 mRNA in the P3 neuron (relative to actin mRNA measured in the same cell) was $14 \%$ of that in P25 neurons. These data show that the developmental changes in $\mathrm{K}^{+}$-coupled and furosemide-sensitive $\mathrm{Cl}^{-}$accumulation and extrusion are correlated with the expression of KCC2 mRNA and reinforce the role of KCC2 in the developmental shift to lowered $\left[\mathrm{Cl}^{-}\right]_{\mathrm{i}}$.

\section{Functional consequences of thermodynamic driving forces for cotransporters}

The results presented above support the role of $\mathrm{KCC} 2$ in both accumulation and extrusion of $\mathrm{Cl}^{-}$under physiological conditions. To determine whether this action of KCC2 is consistent with the chemical forces acting on the transporter, we used a theoretical model to predict the thermodynamic driving forces as a function of $\left[\mathrm{Cl}^{-}\right]_{\mathrm{i}}$ and $\left[\mathrm{K}^{+}\right]_{\mathrm{o}}$. The direction of transport of an electroneutral cotransporter is governed by the chemical potentials of the ions transported [derived from Stein (1990), Eq. 2.3]:

$$
U=R T \sum_{j=1}^{n} m_{j} \ln \left(\frac{\left[X_{j}\right]_{\mathrm{in}}}{\left[X_{j}\right]_{\mathrm{out}}}\right)
$$

where $n$ is the number of different ion species transported (KCC2, $n=2$; NKCC, $n=3), m_{j}$ is the number of molecules transported for each species (for NKCC, $m_{\mathrm{C} 1}=2 ; m=1$ otherwise), $\left[X_{j}\right]_{\text {in }}$ and $\left[X_{j}\right]_{\text {out }}$ are the concentrations of ion species $j$ inside and outside the cell, and $R T$ is the product of the gas constant and absolute temperature. The thermodynamic driving force $(U)$ is plotted in Figure 7 for two chloride cotransporter subtypes: NKCC and $\mathrm{KCC} 2$. The direction of transport in NKCC is relatively insensitive 


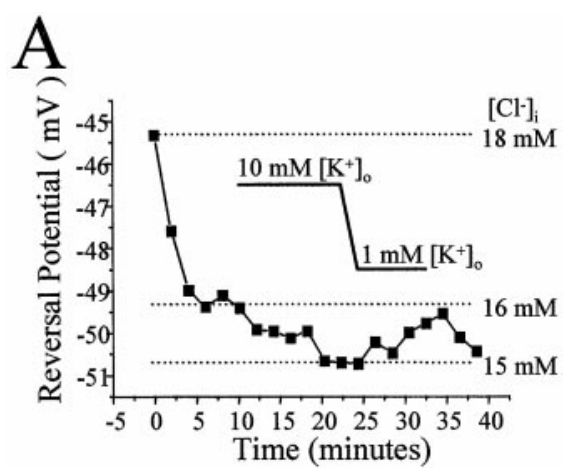

B

Figure 6. Single-cell rt-PCR of neurons from neocortica slices reveals developmentally regulated expression of KCC2 RNA. $A$, Manipulations of $\left[\mathrm{K}^{+}\right]_{\mathrm{o}}$ had no effect in this example recording from a $\mathrm{P} 3$ neuron with $20 \mathrm{~mm}$ pipette $\mathrm{Cl}^{-} . B$, The mean changes in reversal potential and calculated $\left[\mathrm{Cl}^{-}\right]_{\mathrm{i}}$ were significantly less than those observed in P18-P28 neurons. Data from both 1 and $20 \mathrm{~mm}$ pipette $\mathrm{Cl}^{-}$were pooled. $C$, Single neurons were analyzed from neocortical slices of $\mathrm{P} 3$ or P25 rats. rt-PCR, as described in Materials and Methods, was used to amplify a specific KCC2 fragment from pyrami$\mathrm{dal}$ neurons or interneurons. Control lanes $(C)$ refer to rtPCR performed on samples taken by aspirating extracellularly within the slice. $D$, Cell contents from several of the cells in $C$ were subjected to rt-PCR amplification of both $\mathrm{KCC} 2$ and actin.

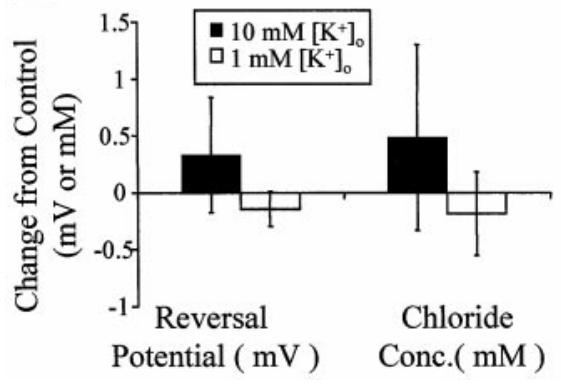

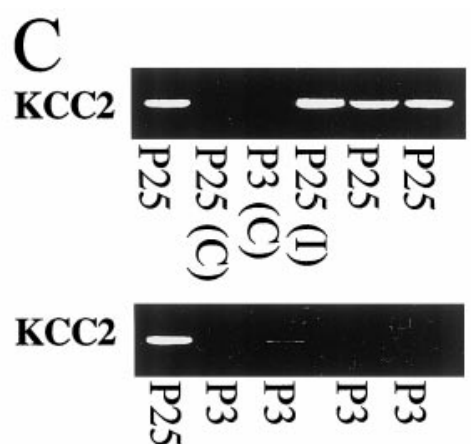

D

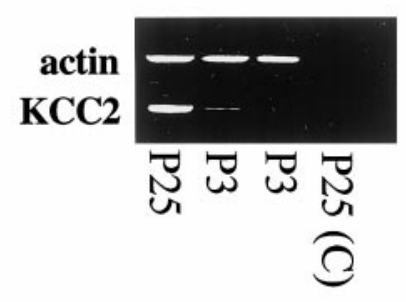

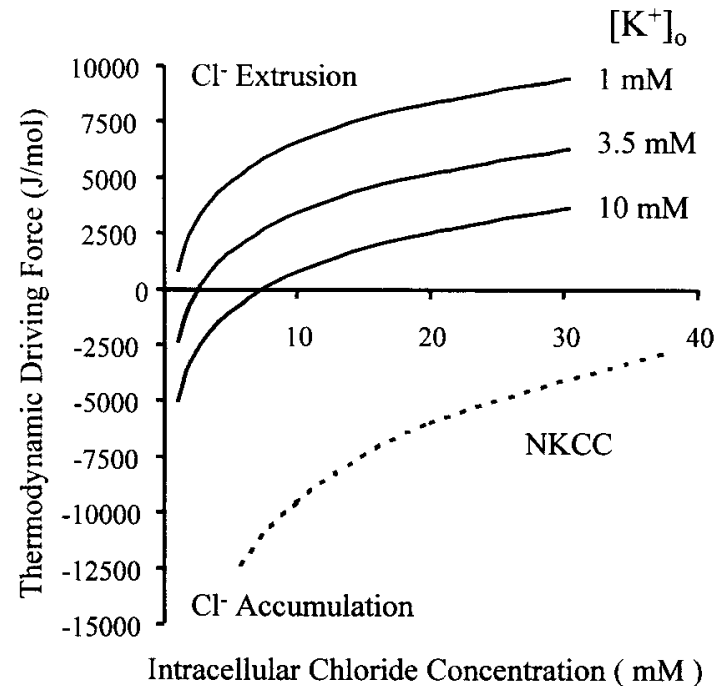

Figure 7. The thermodynamic driving force determines the direction of electroneutral $\mathrm{Cl}^{-}$cotransport. The $x$-axis represents the intracellular $\mathrm{Cl}^{-}$ concentration. Along the $y$-axis, positive values of the driving force represent $\mathrm{Cl}^{-}$extrusion, whereas negative values indicate $\mathrm{Cl}^{-}$accumulation. The sum of the chemical potentials of $\mathrm{Na}^{+}, \mathrm{K}^{+}$, and $2 \mathrm{Cl}^{-}$inside and outside the cell as a function of intracellular $\mathrm{Cl}^{-}$concentration is represented by the dashed line for $3.5 \mathrm{~mm}\left[\mathrm{~K}^{+}\right]$. The solid lines represent the driving force for the cotransport of both $\mathrm{K}^{+}$and $\mathrm{Cl}^{-}$(thus $\mathrm{KCC} 2$ ) at different $\left[\mathrm{K}^{+}\right]_{\mathrm{o}}$. The gray shaded region represents the range of ion concentrations that give rise to intracellular $\mathrm{K}-\mathrm{Cl}$ accumulation; thus at elevated $\left[\mathrm{K}^{+}\right]_{0}$ and low $\left[\mathrm{Cl}^{-}\right]_{\mathrm{i}}$, thermodynamic calculations predict that the $\mathrm{KCC} 2$ activity will raise intracellular $\mathrm{Cl}^{-}$.

to changes in $\left[\mathrm{Cl}^{-}\right]_{\mathrm{i}}$ or $\left[\mathrm{K}^{+}\right]_{\mathrm{o}}$ over the range of physiological concentrations of the two ions. However, the direction of KCC2 transport is sensitive to small changes in $\left[\mathrm{Cl}^{-}\right]_{\mathrm{i}}$ and $\left[\mathrm{K}^{+}\right]_{\mathrm{o}}$ near physiological levels. Below the expected $\left[\mathrm{Cl}^{-}\right]_{\mathrm{i}}$ for mature pyramidal cells $[\sim 10 \mathrm{~mm}$ (R. A. DeFazio and S. Keros, unpublished observations)], $\mathrm{KCC} 2$ is predicted to accumulate intracellular chloride when $\left[\mathrm{K}^{+}\right]_{\mathrm{o}}$ is $>1 \mathrm{~mm}$ (Fig. 7 , gray shaded region).

\section{DISCUSSION}

Our results demonstrate the existence of a powerful homeostatic mechanism that maintains intracellular $\mathrm{Cl}^{-}$concentration. De- spite whole-cell dialysis with the low $\mathrm{Cl}^{-}$pipette solution, $\mathrm{K}^{+}-$ $\mathrm{Cl}^{-}$cotransport activity raised the calculated intracellular $\mathrm{Cl}^{-}$ concentration by $0.7-1.6 \mathrm{~mm}$. This is a net change in $\mathrm{Cl}^{-}$concentration; in light of the continuous dialysis of the cell with the low $\mathrm{Cl}^{-}$pipette solution, it is likely that the pumps were accumulating substantially more than $\sim 1 \mathrm{~mm}$ chloride. Likewise despite elevated pipette $\mathrm{Cl}^{-}$concentrations, reversal potentials indicated intracellular $\mathrm{Cl}^{-}$concentrations well below those calculated from excised patches. This implies that the pumps were extruding at least several millimolar $\mathrm{Cl}^{-}$. It is unlikely that NKCC, the pump traditionally associated with $\mathrm{Cl}^{-}$accumulation, plays a role under these recording conditions because both lowering extracellular potassium (affecting only $\mathrm{K}^{+}-\mathrm{Cl}^{-}$cotransport) and cotransport antagonism with furosemide (affecting both $\mathrm{NKCC}$ and $\mathrm{K}^{+}-\mathrm{Cl}^{-}$cotransport) lowered intracellular $\mathrm{Cl}^{-}$to levels similar to those obtained in excised patches. This surprising result suggests that $\mathrm{K}^{+}-\mathrm{Cl}^{-} \mathrm{co}^{-}$ transport function alone is sufficient for the homeostatic maintenance of intracellular $\mathrm{Cl}^{-}$; i.e., under these recording conditions, $\mathrm{K}^{+}-\mathrm{Cl}^{-}$cotransport is both the primary extrusion and accumulation mechanism in mature neocortical neurons.

Bicarbonate flux has been proposed to be a major contributor to $\mathrm{GABA}_{\mathrm{A}}$ receptor function (Kaila et al., 1993; Staley and Proctor, 1999). Our initial finding that the reversal potential with low pipette $\mathrm{Cl}^{-}$was much more depolarized than those obtained in excised patches could be interpreted to reflect a strong bicarbonate flux (see Materials and Methods). However, when $\mathrm{Cl}^{-}$accumulation via $\mathrm{K}^{+}-\mathrm{Cl}^{-}$cotransport was reduced by lowering extracellular potassium or by cotransport antagonism with furosemide, the reversal potentials were no longer significantly different from those of excised patches, which lacked a bicarbonate component. These manipulations of extracellular potassium and cotransport antagonism are not expected to modify intracellular or extracellular bicarbonate. These results support the contention that the depolarized reversal observed with low pipette $\mathrm{Cl}^{-}$was caused by $\mathrm{Cl}^{-}$ accumulation via $\mathrm{K}^{+}-\mathrm{Cl}^{-}$cotransport and not by an unmasked bicarbonate efflux. Bicarbonate can be an important component of GABA responses (Kaila et al., 1993, 1997; Staley and Proctor, 1999); however, under the present recording conditions bicarbonate did not appear to play a major role in determining the response to GABA. A lack of a bicarbonate contribution to depolarizing GABA responses in hippocampal pyramidal cells has also been reported (Grover et al., 1993). 
Differential expression of the transport proteins involved in $\mathrm{Cl}^{-}$ homeostasis has been proposed to explain differences in resting $\mathrm{Cl}^{-}$concentrations between cell types (Rohrbough and Spitzer, 1996; Ulrich and Huguenard, 1997) and during development (Owens et al., 1996; Kakazu et al., 1999; Rivera et al., 1999). The absence of $\mathrm{K}^{+}$-coupled $\mathrm{Cl}^{-}$cotransport in our recordings from neonatal neurons correlated well with the reduced expression of KCC2 mRNA detected in single-cell harvests. Although other extrusion mechanisms must exist in neonatal neurons, the absence of a potassium-coupled mechanism is consistent with the elevated intracellular $\mathrm{Cl}^{-}$concentration reported in neonatal neurons. In addition, because of a role for neuronal $\mathrm{K}^{+}-\mathrm{Cl}^{-}$cotransport in the maintenance of extracellular potassium (Payne, 1997), the lack of KCC2 expression in neonatal neurons may explain differences in extracellular potassium regulation observed during development (Hablitz and Heinemann, 1989).

The presence of a powerful potassium-coupled $\mathrm{Cl}^{-}$cotransport mechanism has important functional implications. Our results suggest that $\mathrm{K}^{+}-\mathrm{Cl}^{-}$cotransport alone is sufficient for homeostatic maintenance of intracellular $\mathrm{Cl}^{-}$. The $\mathrm{Cl}^{-}$set point (the concentration at which the pump exhibits no net flux) is coupled to $\left[\mathrm{K}^{+}\right]_{\mathrm{o}}$. If intracellular $\mathrm{Cl}^{-}$exceeds the set point, $\mathrm{K}^{+}{ }_{-} \mathrm{Cl}^{-}$cotransport can extrude $\mathrm{Cl}^{-}$. If $\mathrm{Cl}^{-}$goes below the set point, $\mathrm{K}^{+}-\mathrm{Cl}^{-}$cotransport can accumulate $\mathrm{Cl}^{-}$. We have demonstrated the capacity of these pumps to maintain intracellular $\mathrm{Cl}^{-}$concentrations despite wholecell dialysis via a patch pipette. Such a $\mathrm{Cl}^{-}$load or sink is substantially less than the physiological $\mathrm{Cl}^{-}$load or sink because of $\mathrm{GABA}_{\mathrm{A}}$ receptor-mediated $\mathrm{Cl}^{-}$flux, thus demonstrating reserve capacity, an important aspect of numerous physiological systems. It is clear that other $\mathrm{Cl}^{-}$homeostatic mechanisms are present in the neuron. For example, the $\mathrm{Cl}^{-}$reversal potential is still quite hyperpolarized in neurons from P3 to P6 animals, suggesting that although immature cells have reduced $\mathrm{KCC} 2$ mRNA levels some other mechanism is lowering intracellular $\mathrm{Cl}^{-}$.

Payne (1997) proposed that KCC2 could contribute to extracellular potassium homeostasis. Although the relative contribution of neurons to the spatial buffering of extracellular potassium remains to be determined, one of the primary consequences of a rise in extracellular potassium would be elevation of the intracellular $\mathrm{Cl}^{-}$ concentration. In our experiments, raising extracellular potassium from 3.5 to $10 \mathrm{~mm}$ increased intracellular $\mathrm{Cl}^{-} \sim 3 \mathrm{~mm}$ (with either 1 or $20 \mathrm{~mm}$ pipette $\mathrm{Cl}^{-}$). A $3 \mathrm{~mm}$ increase in intracellular $\mathrm{Cl}^{-}$from a resting $\mathrm{Cl}^{-}$concentration of $10 \mathrm{~mm}$ would raise the $\mathrm{Cl}^{-}$reversal potential from -61 to $-54 \mathrm{mV}$. Under these conditions, activation of $\mathrm{GABA}_{\mathrm{A}}$ receptors could depolarize the cell to $-54 \mathrm{mV}$, much closer to the threshold for action potential generation in neocortical neurons. Large increases in extracellular potassium have been described during seizure-like activity both in vivo (Lux et al., 1974; Xiong and Stringer, 1999) and in vitro (Benninger et al., 1980; Swann et al., 1986; Hablitz and Heinemann, 1989). It is possible that elevations in neuronal $\mathrm{Cl}^{-}$could contribute to the difficulty in controlling prolonged seizures.

The net effect on excitability of a $\mathrm{K}^{+}$-dependent accumulation of intracellular $\mathrm{Cl}^{-}$is not clear. A rise in extracellular potassium has multiple effects on neurons; in addition to increased intracellular $\mathrm{Cl}^{-}$, input resistance decreases and the membrane potential depolarizes. In the present study at a holding potential of $-70 \mathrm{mV}$, raising extracellular potassium from 3.5 to $10 \mathrm{~mm}$ decreased the input resistance by $41 \pm 10 \mathrm{M} \Omega$ and induced a depolarizing current of $388 \pm 122 \mathrm{pA}$. To a considerable degree the most prominent effect of an acute increase in extracellular potassium is membrane depolarization such as that described by Kaila et al. (1997). They demonstrated an $\sim 20 \mathrm{mV}$ depolarization because of a transient increase in extracellular potassium of up to $7.4 \mathrm{~mm}$ in response to a high-frequency stimulus train. Such a depolarization is sufficient to place the membrane potential above the elevated $\mathrm{Cl}^{-}$reversal potential and result in a hyperpolarizing response to synaptic GABA. Neuronal buffering of extracellular potassium probably does not have pathological consequences for neuronal function because the elevated intracellular $\mathrm{Cl}^{-}$concentration is balanced by a decrease in input resistance and membrane depolarization.

Recent studies suggest a strong neuronal contribution to buffering of $\left[\mathrm{K}^{+}\right]_{\mathrm{o}}$ (Ransom et al., 2000; Xiong and Stringer, 2000). It is difficult to infer a direct role of $\mathrm{KCC} 2$ in these studies because the manipulations that would affect the cotransporter also altered the spontaneous activity that gave rise to the potassium transient. Lowering extracellular $\mathrm{Cl}^{-}$, furosemide, and ouabain all raised the ceiling of the extracellular potassium transient (Xiong and Stringer, 2000). Although Xiong and Stringer conclude a role for the neuronal $\mathrm{Na}^{+}-\mathrm{K}^{+}$ATPase, it is clear that breakdown of the potassium gradient because of inhibition of the $\mathrm{Na}^{+}-\mathrm{K}^{+}$ATPase could also inhibit $\mathrm{K}^{+}$-coupled $\mathrm{Cl}^{-}$cotransport. $\mathrm{KCC} 2$-mediated $\mathrm{Cl}^{-}$accumulation in elevated $\left[\mathrm{K}^{+}\right]_{\mathrm{o}}$ is consistent with an enhancement of the capacity of the homeostatic mechanisms that regulate extracellular $\mathrm{K}^{+}$. In addition to its major role in neuronal $\mathrm{Cl}^{-}$ homeostasis, $\mathrm{KCC} 2$ expression may result in a more rapid return to normal levels of $\left[\mathrm{K}^{+}\right]_{\mathrm{o}}$ and/or a lower maximal level that $\left[\mathrm{K}^{+}\right]_{\mathrm{o}}$ can attain.

In summary, we have shown that developmental changes in the expression of $\mathrm{KCC} 2$ result in the coupling of $\left[\mathrm{Cl}^{-}\right]_{\mathrm{i}}$ and $\left[\mathrm{K}^{+}\right]_{\mathrm{o}}$ via the activity of the furosemide-sensitive $\mathrm{K}^{+}$-coupled $\mathrm{Cl}^{-}$cotransporter. $\left[\mathrm{K}^{+}\right]_{\mathrm{o}}$ manipulations in immature neurons had no effect on $\left[\mathrm{Cl}^{-}\right]_{\mathrm{i}}$, consistent with the low expression of KCC2 mRNA detected in cytoplasm harvested from these cells. Expression of $\mathrm{KCC} 2$ results in lowered $\left[\mathrm{Cl}^{-}\right]_{\mathrm{i}}$ and translates physiological changes in $\left[\mathrm{K}^{+}\right]_{\mathrm{o}}$ to marked changes in $\left[\mathrm{Cl}^{-}\right]_{\mathrm{i}}$. These data demonstrate a physiologically relevant and developmentally regulated role for $\mathrm{KCC} 2$ in $\mathrm{Cl}^{-}$homeostasis and neuronal excitability.

\section{REFERENCES}

Alvarez-Leefmans $\mathrm{FJ}$ (1990) Intracellular $\mathrm{Cl}^{-}$regulation and synaptic inhibition in vertebrate and invertebrate neurons. In: Chloride channels and carriers in nerve, muscle, and glial cells (Alvarez-Leefmans FJ, Russel JM, eds), pp 109-158. New York: Plenum.

Andersen P, Dingledine R, Gjerstad L, Langmoen IA, Laursen AM (1980) Two different responses of hippocampal pyramidal cells to application of gamma-aminobutyric acid. J Physiol (Lond) 305:279-296.

Barker JL, Harrison NL (1988) Outward rectification of inhibitory postsynaptic currents in cultured rat hippocampal neurones. J Physiol (Lond) 403:41-55.

Benninger C, Kadis J, Prince DA (1980) Extracellular calcium and potassium changes in hippocampal slices. Brain Res 187:165-182.

Bormann J, Hamill OP, Sakmann B (1987) Mechanism of anion permeation through channels gated by glycine and gamma-aminobutyric acid in mouse cultured spinal neurones. J Physiol (Lond) 385:243-286.

Devay P, McGehee DS, Yu CR, Role LW (1999) Target-specific control of nicotinic receptor expression at developing interneuronal synapses in chick. Nat Neurosci 2:528-534.

Dreif uss JJ, Kelly JS, Krnjevic K (1969) Cortical inhibition and gammaaminobutyric acid. Exp Brain Res 9:137-154.

Grover LM, Lambert NA, Schwartzkroin PA, Teyler TJ (1993) Role of $\mathrm{HCO}_{3}{ }^{-}$ions in depolarizing $\mathrm{GABA}_{\mathrm{A}}$ receptor-mediated responses in pyramidal cells of rat hippocampus. J Neurophysiol 69:1541-1555.

Hablitz JJ, Heinemann U (1989) Alterations in the microenvironment during spreading depression associated with epileptiform activity in the immature neocortex. Dev Brain Res 46:243-252.

Howe JR, Sutor B, Zieglgansberger W (1987) Characteristics of longduration inhibitory postsynaptic potentials in rat neocortical neurons in vitro. Cell Mol Neurobiol 7:1-18.

Jarolimek W, Lewen A, Misgeld U (1999) A furosemide-sensitive $\mathrm{K}^{+}$$\mathrm{Cl}^{-}$cotransporter counteracts intracellular $\mathrm{Cl}^{-}$accumulation and depletion in cultured rat midbrain neurons. J Neurosci 19:4695-4704.

Kaila K, Voipio J, Paalasmaa P, Pasternack M, Deisz RA (1993) The role of bicarbonate in $\mathrm{GABA}_{\mathrm{A}}$ receptor-mediated IPSPs of rat neocortical neurones. J Physiol (Lond) 464:273-289.

Kaila K, Lamsa K, Smirnov S, Taira T, Voipio J (1997) Long-lasting GABA-mediated depolarization evoked by high-frequency stimulation in pyramidal neurons of rat hippocampal slice is attributable to a networkdriven, bicarbonate-dependent $\mathrm{K}^{+}$transient. J Neurosci 17:7662-7672.

Kakazu Y, Akaike N, Komiyama S, Nabekura J (1999) Regulation of intracellular chloride by cotransporters in developing lateral superior olive neurons. J Neurosci 19:2843-2851.

Kakazu Y, Uchida S, Nakagawa T, Akaike N, Nabekura J (2000) Reversibility and cation selectivity of the $\mathrm{K}^{+}-\mathrm{Cl}^{-}$cotransport in rat central neurons. J Neurophysiol 84:281-288.

Krnjevic K, Schwartz S (1967) The action of gamma-aminobutyric acid on cortical neurones. Exp Brain Res 3:320-336.

Ling DS, Benardo LS (1995) Activity-dependent depression of monosyn- 
aptic fast IPSCs in hippocampus: contributions from reductions in chloride driving force and conductance. Brain Res 670:142-146.

Lu J, Karadsheh M, Delpire E (1999) Developmental regulation of the neuronal-specific isoform of the K-Cl cotransporter in postnatal rat brains. J Neurobiol 39:558-568.

Lux HD, Heinemann U, Dietzel I (1974) Ionic changes and alterations in the size of the extracellular space during epileptic activity. In: Advances in neurology, Vol 44 (Delgado-Escueta AV, Ward Jr AA, Woodbury DM, Porter RJ, eds), pp 619-639. New York: Raven.

Neher E (1992) Correction for liquid junction potentials in patch clamp experiments. Methods Enzymol 207:123-131.

Owens DF, Boyce LH, Davis MB, Kriegstein AR (1996) Excitatory GABA responses in embryonic and neonatal cortical slices demonstrated by gramicidin perforated-patch recordings and calcium imaging. J Neurosci 16:6414-6423.

Payne JA (1997) Functional characterization of the neuronal-specific $\mathrm{K}^{+}$$\mathrm{Cl}^{-}$cotransporter: implications for $\left[\mathrm{K}^{+}\right]_{\mathrm{o}}$ regulation. Am J Physiol 273:C1516-C1525.

Poth K, Nutter TJ, Cuevas J, Parker MJ, Adams DJ, Luetje CW (1997) Heterogeneity of nicotinic receptor class and subunit mRNA expression among individual parasympathetic neurons from rat intracardiac ganglia. J Neurosci 17:586-596.

Ransom CB, Ransom BR, Sontheimer H (2000) Activity-dependent extracellular $\mathrm{K}^{+}$accumulation in rat optic nerve: the role of glial and axonal $\mathrm{Na}^{+}$pumps. J Physiol (Lond) 522:427-442.

Rivera C, Voipio J, Payne JA, Ruusuvuori E, Lahtinen H, Lamsa K, Pirvola U, Saarma M, Kaila K (1999) The $\mathrm{K}^{+} / \mathrm{Cl}^{-}$co-transporter KCC2 renders GABA hyperpolarizing during neuronal maturation. $\mathrm{Na}-$ ture 397:251-255.

Robinson RA, Stokes RH (1959) Electrolyte solutions. London: Butterworths.

Rohrbough J, Spitzer NC (1996) Regulation of intracellular Cl- levels by $\mathrm{Na}^{+}$-dependent $\mathrm{Cl}^{-}$cotransport distinguishes depolarizing from hyperpolarizing $\mathrm{GABA}_{\mathrm{A}}$ receptor-mediated responses in spinal neurons. J Neurosci 16:82-91.
Sakmann B, Neher E (1995) Single-channel recording. New York: Plenum.

Staley KJ, Proctor WR (1999) Modulation of mammalian dendritic GABA receptor function by the kinetics of $\mathrm{Cl}^{-}$and $\mathrm{HCO}^{-}$transport. J Physiol (Lond) 519:693-712.

Stein WD (1990) Channels, carriers, and pumps: an introduction to membrane transport. San Diego: Academic.

Swann JW, Smith KL, Brady RJ (1986) Extracellular K ${ }^{+}$accumulation during penicillin-induced epileptogenesis in the CA3 region of immature rat hippocampus. Brain Res 395:243-255.

Thompson SM, Gähwiler BH (1989a) Activity-dependent disinhibition. I. Repetitive stimulation reduces IPSP driving force and conductance in the hippocampus in vitro. J Neurophysiol 61:501-511.

Thompson SM, Gähwiler BH (1989b) Activity-dependent disinhibition. II. Effects of extracellular potassium, furosemide, and membrane potential on $\mathrm{E}_{\mathrm{Cl}}$ - in hippocampal CA3 neurons. J Neurophysiol 61:512-523.

Thompson SM, Deisz RA, Prince DA (1988a) Outward chloride/cation co-transport in mammalian cortical neurons. Neurosci Lett 89:49-54.

Thompson SM, Deisz RA, Prince DA (1988b) Relative contributions of passive equilibrium and active transport to the distribution of chloride in mammalian cortical neurons. J Neurophysiol 60:105-124.

Ulrich D, Huguenard JR (1997) Nucleus-specific chloride homeostasis in rat thalamus. J Neurosci 17:2348-2354.

Weiss DS, Hablitz JJ (1984) Interaction of penicillin and pentobarbital with inhibitory synaptic mechanisms in neocortex. Cell Mol Neurobiol 4:301-317.

Williams JR, Sharp JW, Kumari VG, Wilson M, Payne JA (1999) The neuron-specific K-Cl cotransporter, KCC2. Antibody development and initial characterization of the protein. J Biol Chem 274:12656-12664.

Xiong Z, Stringer J (2000) Sodium pump activity, not glial spatial buffering, clears potassium after epileptiform activity induced in the dentate gyrus. J Neurophysiol 83:1443-1451.

Xiong ZQ, Stringer JL (1999) Astrocytic regulation of the recovery of extracellular potassium after seizures in vivo. Eur J Neurosci 11:16771684 . 